\title{
Middle School Teachers' Knowledge and Use of Comprehension Strategies in Discipline Instruction
}

\author{
Elsa R. Barron and William H. Rupley \\ Texas A\&M University \\ College Station, Texas \\ David Paige \\ Bellarmine University \\ Louisville, Kentucky \\ William Dee Nichols and Janet Nichols \\ The University of Maine \\ Orono, Maine \\ Ricardo Lumbreras, Jr. \\ Tarleton State University \\ Stephenville, Texas
}

\begin{abstract}
This mixed method study investigated the total minutes 6 Social Studies and 6 English-Language Arts seventh grade-teachers taught and used comprehension strategies in their discipline area teaching. Three 45-minute observations of each teachers were used to determine reading comprehension strategies taught by individual teachers. Measures of teachers acquired reading comprehension strategy knowledge were compiled through focused interviews and a questionnaire. Reported practices and knowledge were compared to the observations of their classroom instruction. Interview and questionnaire data were analyzed using coding to identify patterns, themes, and repetition of words or key words, and use of phrases or sentences that reveal similarities of participants' strategy instruction. Data revealed all 12 teachers spent only 89 minutes on comprehension strategy instruction, representing $5.5 \%$ of their total instructional time. Forty-two percent of the teachers indicated that they received training from a State Region Education Service Center, college and university courses, and district initiatives.
\end{abstract}

Keywords: reading comprehension strategies; discipline area instruction; reading strategies; middle school. 


\section{Introduction}

Despite the United States' implementation of educational reforms and the Common Core State Standards Initiative (2010), many students continue to lag behind in all areas of reading, especially reading comprehension. For decades, the National Assessment of Educational Progress (NAEP, 2015) has provided what amounts to a national reading assessment. At the proficient level on the NAEP, eighth-grade students reading should be able to locate information, identify statements of main idea, theme, or author's purpose, and make and support their inferences from texts. These capabilities are focused on comprehension and learning from discipline text. As a result, students should also be able to make causal interpretations as well as be able to generate and provide support regarding an author's position. NAEP (2015) reports the percentage of students reading below the proficient level in the eighth grade is $66 \%$, a level that has changed little in almost three decades. The purpose of this study is to provide insight into the extent to which seventh grade content teachers provide instruction to assist students with comprehension of discipline area texts.

Reading comprehension is defined as the process of simultaneously extracting and constructing meaning through interaction and involvement with written language (Snow, 2002; McLaughlin, 2012). Neufeld (2005) defines comprehension as constructing a supportable understanding of a text. In addition, components of reading comprehension such as prior knowledge of the content to be read have been identified. Topics such as what the reader knows about the topic and the ideas conveyed through the words printed in the text are important to the comprehension and learning processes (Cunningham \& Stanovich, 1997; Hirsch, 2003; Neufeld, 2005).

Teaching students to learn from their reading in discipline texts is a complex process that requires teachers to be knowledgeable about a wide range of instructional strategies and designs. The role of the teacher is becoming ever more demanding with the increasing federal and district level pressures associated with high stakes testing and accountability. As a result, the solution to meet the increased demands of accountability often results in teachers gearing instruction to focus on state mandated tests rather than teaching higher level thinking skills and instructional strategies aimed at facilitating comprehension within the discipline areas (Author, 2018). The task of teaching and improving reading to learn is not an easy one; it is a challenge that involves several elements, including teaching meaningful strategies reflective of the discipline and knowing how to implement these for the student to succeed throughout his/her middle, and high school grades (Snow, 2002).

\section{Comprehension Strategy Instruction Importance}

Graesser (2007) states that knowledge of reading strategies is important if readers are to develop comprehension at the situational model level, which is the level of "coherence, perspective taking, translation, updating knowledge, and learning from multiple sources" (Diesen, 2014,p. 33). Efficiently unlocking words from print (extracting) while developing a description of the decoded 
information (constructing meaning) are the two main challenges to reading comprehension (Snow, 2002). Most often this involves explicit strategy teaching as many students need teachers to model the strategies, provide guided practice, and allow time to practice the strategies independently in order to reach their fullest potential (Prado \& Plourde, 2011; Rudd, 2007; Stockard, 2014). Discipline area teachers are recommended to use direct instruction of text structure and genres, language usage, norms of accuracy and preciseness, and higher-level interpretive processes (Shanahan \& Shanahan, 2008).

Many reading strategies can be explicitly imbedded and used in meaningful practice while students are being expected to learn from discipline texts that are beyond their instructional level. Research-based reading comprehension strategies can provide the necessary scaffolding for effective reading instruction (Cecil, Gipe, \& Merrill, 2014). What is essential is that the strategies are based on both the needs of students and the knowledge of what works in improving students' discipline learning. If the use of strategies is woven throughout discipline area reading, such instruction has the potential to nurture and facilitate further reading development and enhance students' learning (Jacobs, 2002). Related research findings (e.g., Grimes, 2004; National Middle School Association, 2006) are clear that instruction within discipline area teaching must help students understand, practice, and apply relevant reading strategies to their learning from text. In essence, students need to be explicitly taught when and under what circumstances they should apply particular instructional strategies and how the use of such strategies benefits their learning (Shanahan, 2016).

Strategic knowledge is an essential component of understanding and learning from texts. Recent research has shown that knowledge of reading strategies in fourth-grade effects fifth-grade reading comprehension when controlling for fluency, vocabulary, working memory (Muijselaar et al., 2017). However, not all students realize the importance of these comprehension strategies and are unable to draw upon them during reading (Barton \& Sawyer, 2004). While there is a fairly consistent agreement within the field (National Institute for Child Health and Human Development, 2001) about the characteristics of effective reading instruction in the earlier grades, there is less agreement beyond the elementary school (Shanahan \& Shanahan, 2014). It has been reported that almost half of the students entering ninth grade are reading several years below grade level. Furthermore, students entering middle and high school lack the skills and/or strategies to comprehend and learn from discipline grade-level texts (NAPE, 2015).

\section{Strategies for Developing Students' Comprehension}

Researchers have examined the specific strategies readers use to comprehend informational text and have determined that successful reading comprehension relies on automaticity in decoding, prior knowledge, motivation/engagement, understanding the core and related concepts, and use of appropriate processing strategies (Guthrie \& Llauda, 2014; Kletzien, 1991; Weaver \& Kintsch, 1991). Strategies include the learner's understanding of varying the approach to reading depending upon one's goal. Competent readers construct mental 
models of the text by using their existing knowledge along with implementing flexible learning strategies most reflective of the discipline (Shanahan, 2016). When comprehension breaks down, good readers have the awareness necessary to monitor and change these learning strategies so that comprehension is enhanced (Dole, Duffy, Roehler \& Pearson, 1991; Neufeld, 2005). By improving teachers' knowledge of instructional strategies and methods for reading discipline texts, teachers will have a better understanding of the value of these when teaching in their classrooms and a stronger impetus for sharing them with their students (Fowler \& Frey, 2000; McLaughlin, 2012). Strategy instruction in discipline content can be effective when teachers implement a variety of instructional practices in their classrooms (Bryant, Ugel, Thompson, \& Hamff, 1999).

Instructional strategies shown to be effective for teaching reading comprehension include using explicit/direct instruction and advance organizers in outline form; modeling of how to comprehend text; encouraging students to use reading strategies associated with experts within the discipline; providing daily and sustained instruction; expecting strategy mastery; assisting students in learning when, where, and how to apply reading strategies; providing opportunities for students to practice strategies; and understanding that strategy instruction is part of the entire school curriculum and is relevant in other content-area classes (Taylor, 2007; Taylor \& Parsons 2014; Unrau \& Quirk, 2014).

Numerous authors have created lists of strategies that can assist with text comprehension. Davis $(1941,1971)$ created one of the first that includes word knowledge, word meaning within context, understanding passage organization, identifying the main idea, answering text-dependent questions, ability by the reader to express what was read in their own words, the ability to draw inferences from the text, recognize literary devices, and to determine the author's purpose. More than 20 years ago, Rosenshine (1997) summarized comprehension strategy instruction supported by research. A partial list includes developing/activating background knowledge, providing processing opportunities, helping students to organize their knowledge, present new material in small steps, provide procedural prompts, teach cognitive strategies using small steps, provide teacher modeling and think aloud for students, regulate the difficulty of the material, provide procedural cue cards, give feedback and corrections, provide and teach how to use a checklist, provide independent practice with new examples, give student increasing responsibility by decreasing scaffolds, and assess mastery.

Ogle and Blachowicz (2002) identified the use of knowledge and text clues to make predictions, using internal and external features of informational text to predict and monitor, generating questions and elaborations about informational texts, organizing, reorganizing, and summarizing texts, reflecting critically and personally on informational reading, and using oral and written language to formulate, express, and reflect on ideas. Duke and Pearson (2002) suggested that readers should have clear goals in mind for their reading, reviewing the text before reading to make prediction, reading selectively to make decisions about their reading, determining the meaning of unfamiliar words and concepts, 
integrating the text with their prior knowledge, monitoring their understanding of the text, and, thinking about the text before, during, and after reading. The National Reading Panel (National Institute of Child Health and Human Development, 2000) identified empirical evidence for eight strategies including comprehension monitoring, use of graphic organizers, answering and generating questions about the text, summarization, cooperative learning, understanding story structure, and use of multiple strategies during the reading process.

Effective discipline area teachers respond to students' learning needs by varying their instructional procedures and methodologies in relation to desired learning outcomes and their students' capabilities. Furthermore, effective teachers make informed and purposeful decisions about their classroom practices, because they recognize the impact of their instructional design and their related instructional strategy selection on students' learning (Author 2007). What is less known is the extent to which teachers, particularly middle school teachers, include comprehension strategy instruction in their discipline area teaching. This study investigates the extent to which seventh-grade English Language Arts and social studies teachers implement strategy instruction in their classrooms.

The following research questions guided this study:

RQ1: How much time do seventh-grade ELA and social studies teachers spend teaching comprehension strategies?

RQ2: Does the amount of time spent teaching comprehension strategies differ between seventh-grade ELA and social studies teachers?

RQ3: Does the amount of time spent teaching comprehension strategies differ based on whether the teacher is a beginning or seasoned teacher?

RQ4: What are the primary sources from which teachers acquire knowledge about reading comprehension strategies in their discipline area?

\section{Context and Participants}

The 12 teachers participating in the study were selected to represent specific teacher subgroups based on teaching experience and content area (Gall, Gall, \& Borg, 2007). Participants consisted of three beginning, early career English Language Arts/Reading (ELA/R) teachers, three beginning, early career Social Studies (SS) teachers, three seasoned ELA/R teachers and three seasoned SS teachers. All participants taught seventh grade at one of four middle schools in a South Texas, U.S. school district at the time of the study. Teacher participants were aware of the study, but did not know the purpose of the research.

The teacher participants were chosen from each middle school and reflected the skills of either a novice or seasoned teachers, as determined by their number of years teaching. In this research study, teachers with one to three years of experience were considered novice/early career teachers as they were still gaining 
experience (Berliner, 1988). Teachers with 15 or more years of experience were considered seasoned teachers, since it is at this stage that teachers have developed a sense of knowledge about how to handle the classroom (Berliner, 1988). Of the 24 seventh-grade ELA/R and SS teachers who volunteered for the study, 8 met the criteria for a novice teacher ( 3 ELA/R and $5 \mathrm{SS}$ ) and 10 for seasoned (5 ELA/R and 5 SS). The three ELA/R novice teachers were chosen for the study while 3 teachers each from the novice SS and the seasoned ELA/R and SS groups were randomly selected (Gall, Gall, \& Borg, 2007). The teachers had a combined total of 172 years of teaching experience with the novice teachers averaging 2.52 years and the seasoned teachers averaging 26.13. Ten of the participants had attained a Bachelor's degree while two had completed a Master's degree; one participant with a Master's degree was an ELA/R teacher, the other was a SS teacher. The remaining nine participants were certified in the discipline area they were currently teaching.

\section{Data Collection}

Data on teacher implementation of reading comprehension strategies was gathered through the use of the TQG Classroom Observation Form (Author, 2005. )The TQG instrument was selected because it can be modified to specifically address the comprehension instruction components of this study. The TQG instrument consists of queries pertaining to before/during/after reading comprehension activities, vocabulary instructional strategies/practices, and class grouping arrangements and text reading, and materials that were used to deliver instruction. In a study to determine instrument reliability of the TQG Classroom Observation Form (Rupley, 2005) raters were trained on use of the instrument. After training, rater pairs observed three classrooms to further calibrate their use of the instrument. Based on these three classroom observation calibrations, the rater pairs then observed 18 middle school classrooms over the course of two weeks and independently evaluated the reading instruction being implemented by the teacher using the TQG. Statistical analysis resulted in Cohen's Kappa where $\mathrm{K}=.78$ suggesting substantial rater agreement (Landis \& Koch, 1977). The classroom form used for observations is presented in Figure 1.

\begin{tabular}{c|cc|}
$\begin{array}{c}\text { Maximum number of } \\
\text { students observed in } \\
\text { classroom }\end{array}$ & $\begin{array}{l}\text { Number } \\
\text { Maximum number of adults } \\
\text { observed providing } \\
\text { instruction or educational } \\
\text { support in the classroom } \\
\text { (including teacher) }\end{array}$ \\
\hline
\end{tabular}




\section{Comprehension}

\begin{tabular}{|c|c|c|c|}
\hline Before Reading & Models & $\begin{array}{l}\text { Explains, } \\
\text { Reviews }\end{array}$ & $\begin{array}{l}\text { Student } \\
\text { Practice }\end{array}$ \\
\hline \multicolumn{4}{|l|}{$\begin{array}{l}\text { Teacher/student activates prior knowledge } \\
\text { and/or previews text before reading (e.g., uses } \\
\text { advanced organizers, , reviews relevant } \\
\text { content from previous lessons, makes } \\
\text { predictions, makes connections, and ) }\end{array}$} \\
\hline During or After Reading & Models & $\begin{array}{l}\text { Explains, } \\
\text { Reviews }\end{array}$ & $\begin{array}{l}\text { Student } \\
\text { Practice }\end{array}$ \\
\hline \multicolumn{4}{|l|}{$\begin{array}{l}\text { Teacher points out graphic text features } \\
\text { (e.g., sub-heads, captions, charts, maps, } \\
\text { graphs, sidebars, bold and italicized } \\
\text { words) to facilitate interpretation of } \\
\text { text }\end{array}$} \\
\hline \multicolumn{4}{|l|}{$\begin{array}{l}\text { Teacher uses text structure to } \\
\text { teach/identify compare-contrast, cause } \\
\text { effect, or problem-solution }\end{array}$} \\
\hline \multicolumn{4}{|l|}{$\begin{array}{l}\text { Teacher uses explicit comprehension } \\
\text { instruction that teaches students how } \\
\text { to use strategies such as, main idea, } \\
\text { summarizing, drawing conclusions, } \\
\text { visualizing events, evaluating } \\
\text { predictions, identifying fact vs. } \\
\text { opinion, sequencing, monitoring for } \\
\text { comprehension other. Note: Must } \\
\text { involve instruction on "how to" do } \\
\text { something rather than simply soliciting } \\
\text { students to write a main idea for example. }\end{array}$} \\
\hline \multicolumn{4}{|l|}{$\begin{array}{l}\text { Teacher uses explicit comprehension } \\
\text { instruction that teaches students how to } \\
\text { generate questions. }\end{array}$} \\
\hline \multicolumn{4}{|l|}{$\begin{array}{l}\text { Teacher asks students to justify or elaborate } \\
\text { upon their responses (e.g., teacher asks "why", } \\
\text { "how did you reach that conclusion" etc.) }\end{array}$} \\
\hline $\begin{array}{l}\text { Teacher elaborates, clarifies, or link concepts } \\
\text { during text reading, such as an elaboration of } \\
\text { student responses. }\end{array}$ & & & \\
\hline
\end{tabular}




\begin{tabular}{|l|l|}
\hline Vocabulary & Tally \\
\hline Instructional Strategies/Practices & \\
\hline $\begin{array}{l}\text { Teacher activates prior knowledge by using before } \\
\text { reading strategy (e.g., semantic features analysis } \\
\text { map, word web, vocabulary presentation). }\end{array}$ & \\
\hline $\begin{array}{l}\text { Teacher provides an explanation, a definition, or an } \\
\text { example. Before, during or after the lesson. }\end{array}$ & \\
\hline $\begin{array}{l}\text { Teacher elaborates or extends a definition. Examples } \\
\text { are using multiple or contrasting point to refine a } \\
\text { definition; paraphrasing the definition by } \\
\text { incorporating ideas from students' responses, } \\
\text { examples, and experiences; and discussing multiple- } \\
\text { meanings. }\end{array}$ & \\
\hline $\begin{array}{l}\text { Teacher teaches word learning strategies, such as } \\
\text { context clues, word parts, and root meaning. }\end{array}$ & \\
\hline $\begin{array}{l}\text { Teacher requires knowledge of words, such as answer } \\
\text { questions, define words, write sentences, find words } \\
\text { based on clues, notes word parts, and uses context } \\
\text { clues. }\end{array}$ & \\
\hline $\begin{array}{l}\text { Teacher gives students opportunities to apply word } \\
\text { learning strategies, such as using context clues, word } \\
\text { parts, and root meaning. }\end{array}$ & \\
\hline
\end{tabular}

Figure 1: Classroom observation form: Core discipline strategies

To understand how teachers' knowledge about reading comprehension influenced their decisions to provide comprehension instruction in their classes, each of the 12 participants were interviewed by the researchers. Interviews lasted approximately 30 minutes each and followed a protocol of questions. The researchers conducted member checks, a method used to ask participants to confirm their answers to the interview questions, in order to convey the data as accurately as possible (Miller, \& Crabtree, 2005). The following interview questions and statements were asked of all participants and their responses recorded by the researchers.

1. What are some qualities you think a good reader in your discipline should have?

2. In your own words, define what reading comprehension instruction means in your discipline.

3. Do you practice reading comprehension instruction? If so, describe examples of how you provide this type of instruction within you discipline.

4. What are some of the reading comprehension strategies you teach in your class?

5. Describe the process you implement to teach students reading strategies for them to use to facilitate understanding what they read within your discipline. 
Teachers also completed questionnaires focused on descriptive information regarding teaching experience, attained academic degrees, and the source of their reading comprehension strategy instruction knowledge. Training options include regional workshops conducted by their educational cooperative, districtand school-based staff development, department/faculty meetings, and college/ university courses.

\section{Procedures}

Data from the observations were reported in terms of minutes. An example of an observable strategy that pertained to the before reading category included the teacher or student activating prior knowledge and/or previewing text before reading the text. Observable strategies that occurred before, during or after reading included instruction using text features, using text structure to teach/identify compare-contrast, cause and effect, or problem-solution. In order to measure explicit comprehension instruction, the observation form includes categories for main idea, summarizing, drawing conclusions, visualizing events, evaluating predictions, identifying fact versus opinion, sequencing, and monitoring for comprehension. Explicit comprehension instruction that teaches students how to generate questions and justify or elaborate their responses, and the strategies in the during or after reading category included: Teachers asking questions based on text material that required one of the following: making inferences, summarizing/finding main ideas, drawing conclusions, or some other complex skill; and teacher elaborates, clarifies, or links concepts during text reading.

\section{Results}

To fully capture instances of comprehension strategy instruction, each teacher was observed on three occasions during an approximate 45 minute class period. Using the TQG instrument, observers recorded instances of comprehension strategy use. From these data the extent of reading comprehension instruction implemented in the classrooms was evaluated. Teachers are identified not only by English/Language Arts-Reading (ELA/R) and social studies (SS), but also by experience (novice and seasoned), and then by content by experience.

From the time spent observing teachers, three strategies accounted for over $90 \%$ of comprehension instruction time while the remainder were spread across several others, and accounted for a trivial percent of the whole and so are not reported. As noted in Figure 2, Activate Prior Knowledge, Asking Questions, and Elaborate on Responses were the three strategies noted in the observations. 


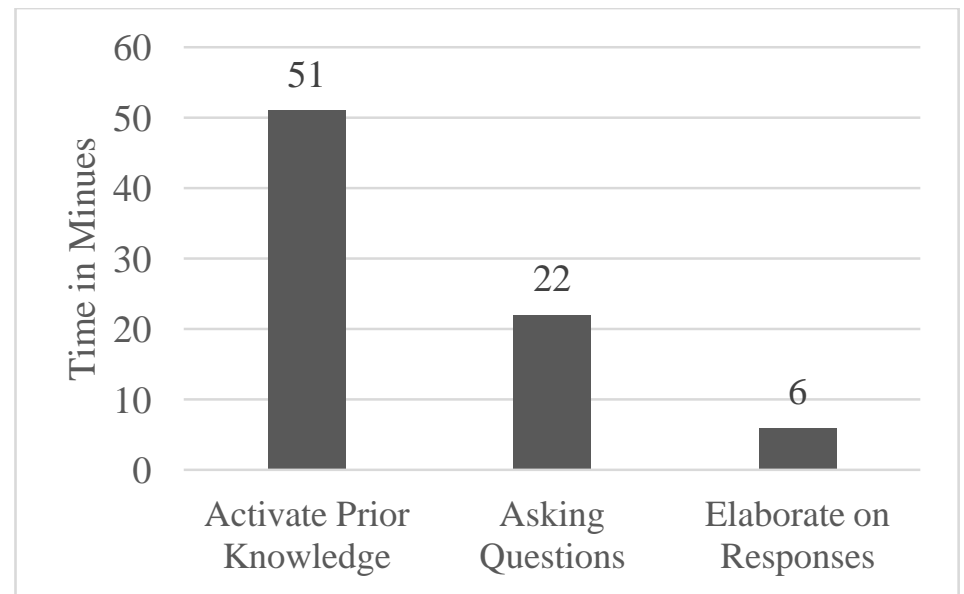

Figure 2: Total Minutes by Strategy Activity for All Teachers

We next analyzed novice ELA/R and SS teachers and the time they spent in comprehension strategy activities. Here, as seen in Figure 3, differences were found as novice ELA/R teachers spent $63(16.0 \%)$ minutes in comprehension activities compared to just $4(1.0 \%)$ for novice SS teachers.

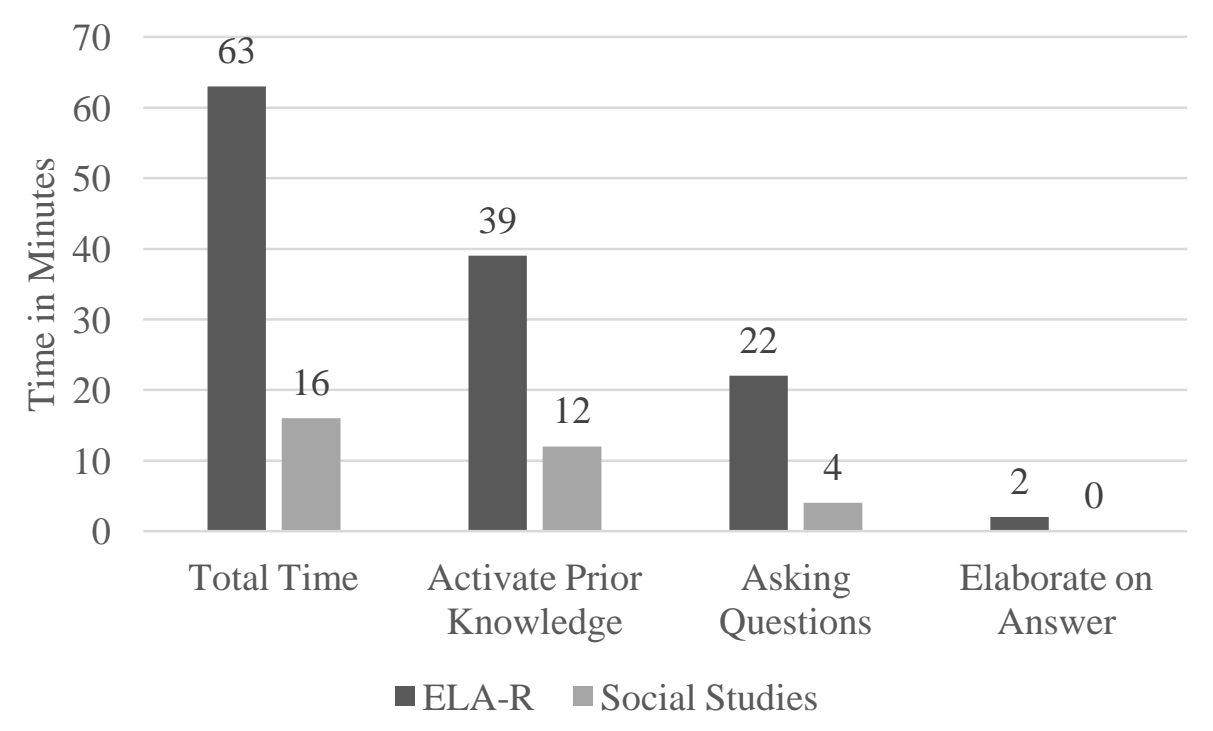

Figure 3: ELA/R and SS novice teachers time spent in strategies for comprehension

Table 1 displays the total amount of time in minutes spent observing a particular teacher group (All teachers, ELA/R/SS, novice/seasoned, novice/seasoned by content, novice by content, seasoned by content) as well as the number of minutes that teachers spent engaged in teaching a particular comprehension strategy. The time for all strategies has been calculated to reveal the percent of time that teachers spent on comprehension activities by teacher group. 
Table 1: Observed time for comprehension strategy instruction by teacher group and strategy

\begin{tabular}{ccccc}
\hline & & \multicolumn{2}{l}{ Time in Minutes by Strategy } & \\
\cline { 3 - 5 } & $\begin{array}{c}\text { All } \\
\text { Strategies } \\
\text { Minutes }(\% \\
\text { of total) }\end{array}$ & $\begin{array}{c}\text { Activating } \\
\text { Prior } \\
\text { Knowledge } \\
\text { Minute (\% of } \\
\text { all strategies) }\end{array}$ & $\begin{array}{c}\text { Asking } \\
\text { Questions } \\
\text { Minutes( } \\
\text { \% of all } \\
\text { strategies) }\end{array}$ & $\begin{array}{c}\text { Elaborating } \\
\text { on Student } \\
\text { Responses } \\
\text { Minutes(\% of } \\
\text { all strategies) }\end{array}$ \\
\hline Group(Total observed minutes) & & $51.0(64.6)$ & $22.0(27.8)$ & $6.0(7.6)$ \\
All Teachers(1,561) & $79.0(5.1)$ & $39.0(61.9)$ & $22.0(34.9)$ & $2.0(3.2)$ \\
ELA-R Teachers(776) & $63.0(8.1)$ & $12.0(75.0)$ & $4.0(25.0)$ & 0 \\
SS Teachers(785) & $16.0(2.0)$ & $39.0(58.2)$ & $22.0(32.8)$ & $6.0(9.0)$ \\
Novice Teachers(786) & $67.0(8.5)$ & $12.0(100.0)$ & 0 & 0 \\
Seasoned Teachers(775) & $12.0(1.5)$ & 0 & 0 & $4.0(100.0)$ \\
Novice ELA-R Teachers(387) & $63.0(16.3)$ & $39.0(61.9)$ & $22.0(34.9)$ & $2.0(3.2)$ \\
Novice SS Teachers(399) & $4.0(1.0)$ & 0 & 0 & 0 \\
Seasoned ELA-R Teachers(389) & $0(0)$ & 0 & 0 & 0 \\
Seasoned SS Teachers(386) & $12.0(3.1)$ & $12.0(100.0)$ & 0 \\
\hline
\end{tabular}

Note. SS = social studies. $n=12$ teachers; ELA-R, $n=6$; Social Studies, $n=6$;

Novice, $n=6$; Seasoned, $n=6$; Novice ELA-R, $n=3$; Novice SS = 3; Seasoned

ELA-R, $n=3$; Seasoned SS, $n=3$.

Table 1 shows that for the 12 participating teachers, comprehension practices were observed for a total of 79 minutes which equates to $5.1 \%$ of observed instructional time. For the the 79 minutes, 51(64.6\%) minutes was spent on activating prior knowledge and/or previewing text before reading, 22(27.8\%) minutes was spent asking questions, and $6(7.6 \%)$ was spent asking student to justify or elaborate on their responses. In sum, of the 79 minutes teachers spent on comprehension strategies, $92 \%$ was spent on two types of activities.

The data were further analyzed for differences in the amount of time devoted to comprehension activities by teacher category. The total observation time was 786 minutes for novice teachers and 775 minutes for seasoned teachers. Here the data revealed large differences as novice teachers spent 67 minutes on comprehension instruction while seasoned teachers spent 12 minutes. Novice teachers spent 39(61.9\%) minutes activating prior knowledge, 22(34.9\%) minutes asking questions, and $2(3.2 \%)$ minutes asking students to elaborate on their answers. Seasoned teachers on the other hand spent $12(100.0 \%)$ minutes in activities to build prior knowledge.

The final comparison group revealed that seasoned ELA/R teachers spent no time in comprehension activities while seasoned SS teachers spent $12(3.1 \%)$ minutes of the observed time on comprehension activities of which $100 \%$ was spent assisting students in activating their prior knowledge.

Interview data were categorized using coding to identify patterns, themes, and repetition of words or key words, and use of phrases or sentences that reveal similarities of participants' strategy instruction. Categorizing the data allowed researchers to note patterns or themes occurring among the majority of the 
participants from the interviews (Perakyla, 2005). In order to unpack the themes or categories both open and axial coding was used. Open coding was the first step used to identify overarching themes or categories. After identifying these categories, axial coding was utilized to interpret or identify other patterns in the data (Berg, 2007). Based on the participants' responses a singular theme was found that participants responses to the interview questions mirrored their classroom practices based on observation data. Coding of the responses reflected a lack of knowledge of comprehension strategy instruction and its importance in discipline area teaching.

All twelve participants completed a questionnaire, which included an openended question that asked them to name the kind of reading comprehension training that had influenced their teaching the most. The responses were used to determine from where did participants receive their knowledge of and professional development training on reading comprehension strategies found in the observation instrument. Table 2 presents the teachers responses to where training/knowledge of reading comprehension strategies were obtained.

Table 2: Sources of teacher's training in reading comprehension strategies

\begin{tabular}{|c|c|c|c|c|c|}
\hline & $\begin{array}{l}\text { Region } \\
\text { Education } \\
\text { Service } \\
\text { Center }\end{array}$ & $\begin{array}{c}\text { District- } \\
\text { based staff } \\
\text { development }\end{array}$ & $\begin{array}{c}\text { Campus- } \\
\text { based staff } \\
\text { development }\end{array}$ & $\begin{array}{l}\text { Department/ } \\
\text { faculty } \\
\text { meetings }\end{array}$ & $\begin{array}{c}\text { College/ } \\
\text { university } \\
\text { courses }\end{array}$ \\
\hline Teacher 1 & $\sqrt{ }$ & $\sqrt{ }$ & $\sqrt{ }$ & $\sqrt{ }$ & $\sqrt{ }$ \\
\hline Teacher 2 & $\sqrt{ }$ & $\sqrt{ }$ & $\sqrt{ }$ & $\sqrt{ }$ & $\sqrt{ }$ \\
\hline Teacher 3 & $\sqrt{ }$ & $\sqrt{ }$ & $\sqrt{ }$ & $\sqrt{ }$ & \\
\hline Teacher 4 & $\sqrt{ }$ & $\sqrt{ }$ & $\sqrt{ }$ & $\sqrt{ }$ & \\
\hline Teacher 5 & $\sqrt{ }$ & $\sqrt{ }$ & $\sqrt{ }$ & $\sqrt{ }$ & $\sqrt{ }$ \\
\hline \multicolumn{6}{|l|}{ Teacher 6} \\
\hline Teacher 7 & $\sqrt{ }$ & $\sqrt{ }$ & $\sqrt{ }$ & $\sqrt{ }$ & $\sqrt{ }$ \\
\hline Teacher 8 & $\sqrt{ }$ & & & & \\
\hline Teacher 9 & & $\sqrt{ }$ & $\sqrt{ }$ & $\sqrt{ }$ & $\sqrt{ }$ \\
\hline Teacher 10 & $\sqrt{ }$ & $\sqrt{ }$ & $\sqrt{ }$ & $\sqrt{ }$ & \\
\hline Teacher 11 & $\sqrt{ }$ & $\sqrt{ }$ & $\sqrt{ }$ & $\sqrt{ }$ & \\
\hline Teacher 12 & $\sqrt{ }$ & $\sqrt{ }$ & $\sqrt{ }$ & & \\
\hline
\end{tabular}

Forty-two percent of the teachers indicated that they received training from a State Region Education Service Center, which was the largest contributor to teachers' training. The remaining sources of the teachers' training were divided among college/university courses, faculty/department/district initiatives, Gifted and Talented seminars; Sheltered Instruction Observation Protocol (SIOP) and Advanced Placement sessions. Some participants 
mentioned other kinds of staff development that was most influential to them. These included Write for the Future, Teaching Reading in Social Studies, classroom experience, and interaction with other experienced teachers.

\section{Discussion and Conclusions}

This study investigated the extent to which comprehension strategy instruction was being implemented by 12 teachers in 7th-grade ELA/R and SS classrooms. Results show that these 12 teachers are spending about $5 \%$ of their classroom time involving students in comprehension strategy instruction. We also found large differences that were dependent on discipline area and teaching experience. As a group, ELA/R teachers spent 63 minutes on comprehension activities compared to 16 for those teaching social studies. Large differences were also found in teacher experience where novice teachers spent 67 minutes involving students in comprehension activities compared to 12 minutes spent by seasoned teachers. Novice ELA/R teachers engaged students in comprehension activities for total of 63 minutes compared to just 4 minutes by social studies teachers. Finally, seasoned social studies teachers spent 12 minutes on comprehension activities compared to 0 minutes by seasoned ELA/R teachers.

Our data suggest that in this sample of teachers it is novice ELA/R teachers who are the primary implementers of reading comprehension strategy activities. Although all of the participants believed they understood the meaning of comprehension strategy instruction, their replies suggested a misunderstanding, or disconnect, when using the terms comprehension and comprehension strategy instruction. When prompted to describe their comprehension instruction, eleven of the participants gave answers indicating they did not understand the meaning of comprehension instruction. Instead, their replies indicated an interpretation of what it means to comprehend when referring to comprehension instruction. This implies that their students' responses to their discipline instruction is defining comprehension and comprehension strategies.

When asked about the implementation of reading comprehension strategies for discipline teaching in their classrooms, only four teachers mentioned summarizing, a reading strategy that improves comprehension (Duke \& Pearson, 2002; Ness, 2007; Vacca \& Vacca, 2005). Approximately five teachers did not seem to be aware of reading comprehension strategies, such as predicting or questioning and instead mentioned writing a journal, noting discipline specific vocabulary, or noting titles and subtitles. These are outcomes rather than strategies, for example rather than "noting titles and subtitles", teachers would be teaching students prior to reading how form questions and predict what the content is going to be about using such text features.

The small number of the teachers who mentioned some of the comprehension instructional activities listed on the observation instrument mirrors the minimal amount of time spent in comprehension instructional practices. Additionally, the participants' answers to the open-ended questions complemented the researchers' observations that comprehension strategies were implemented on a 
minimal basis in their classrooms. Participants were neither able to effectively articulate a definition of comprehension strategy instruction nor did they exhibit adequate knowledge of how to incorporate it into their teaching. It could also be that professional development has not been robust enough to enable them to integrate reading comprehension strategy into their teaching.

\section{Limitations of Study}

A small sample of middle school teachers from one district in an United States state were the focus of this research. In order to expand our knowledge of comprehension and comprehension instructional strategy practices it is recommended that this study be replicated with a larger sample. This information can provide district leaders and administrators a clear picture of the comprehension instruction and strategies utilized by teachers in the schools that can then lead to a targeted professional development plan.

\section{Future Research}

Our results suggest a conflicted perception of the role and importance of comprehension strategy instruction. The fact that just three strategies emerged from our data leads to several compelling questions. First, what is a useful framework for comprehension strategy instruction and second, how much time should be spent on them?

We suggest that a framework of how meaning is created from discipline text by experts within a discipline area can be useful for teachers as they create their understanding of why and how comprehension strategies are useful. Furthermore, a framework using pre-reading instruction should be focused and brief (Shanahan, 2012). Teachers who spend too much time on pre-reading activities prevent students from having enough instructional time to learn and retain the new content (Hollingsworth \& Ybarra, 2009). We offer this as support for the importance of embedding comprehension strategies into discipline area instruction, rather than viewing such strategies as an add on.

\section{References}

Berg, B. L. (2007). Qualitative research methods for the social sciences. Boston, MA: Allyn and Bacon.

Berliner, D. (1988). The development of expertise in pedagogy (Report No. ISBN-0-89333-0531). Washington, DC: American Association of Colleges for Teacher Education. (ERIC Document Reproduction Service No. ED298122)

Bryant, D. P., Ugel, N., Thompson, S., \& Hemff, A. (1999). Instructional strategies for content-area reading instruction. Intervention in School \& Clinic, 34, 293-304. 57(2), 59-69. doi: 10.1080/1045988X.2012.664581

Cecil, N.L., Gipe, J.P., \& Merrill, M. (2014). Literacy in grades 4-8. Best practices for a comprehensive program. Scottsdale, AZ: Holcomb Hathaway.

Common Core State Standards Initiative (2010). Common Core State Standards for English language arts $\mathcal{E}$ literacy in history/social studies, science, and technical subjects. Washington, DC: CCSSO \& National Governors Association.

Cunningham, A. E., \& Stanovich, K. E. (1997). Early reading acquisition and its relation to reading experience and ability 10 years later. Developmental Psychology, 33(6), 934-945. 
Davis, F. B. (1941). Fundamental factors of comprehension in reading. Unpublished doctoral dissertation. Harvard University, Cambridge, MA

Diesen, D. (2014). Situation model: A framework to study reading comprehension. Unpublished Master's Thesis. Department of Cognitive Science, Macquarie University

Dole, J. A., Duffy, G. G., Roehler, L. R., \& Pearson, P. D. (1991). Moving from the old to the new: Research on reading comprehension instruction. Review of Educational Research, 61, 239264.

Duke, N. K., \& Pearson, P. D. (2002). Effective practices for developing reading comprehension. In A. E. Farstrup \& S. J. Samuels (Eds.), What Research Has to Say about reading instruction, ( $3^{\text {rd }}$ ed.) (pp. 205-242). Newark, DE: International Reading Association.

Fowler, D., \& Frey, J. (2000). Teaching phonics in the literature-based classroom. Norwood, MA: Christopher-Gordon Publishers, Inc.

Grimes, S. (2004). The search for meaning. School Library Journal, 50(5), 48-52.

Guthrie, J. T., \& Klauda, S.L. (2014). Effects of Classroom Practices on Reading Comprehension Engagement, and Motivations for Adolescents. Reading Research Quarterly, 49 (4), 387416.

Hall-Kenyon, K.M., \& Black, S. (2010). Learning from expository texts: Classroom-based strategies for promoting comprehension and content knowledge in the elementary grades. Topics in Language Disorders, 30, 339-349.

Heilman, A. W., Blair, T. R., \& Rupley, W. H. (2002). Principles and practices of teaching reading (10 ${ }^{\text {th }}$ ed.). Upper Saddle River, NJ: Merrill Prentice Hall.

Hirsch, E. D., Jr. (2003). Reading comprehension requires knowledge - of words and the world American Educator, Spring, 10-29.

Hollingsworth, J., \& Ybarra, S. (2009). Explicit direct instruction: The power of the wellcrafted, well-taught lesson. Thousand Oaks, CA: Corwin Press.

Jetton, T., Rupley, W.H., \&Wilson, V.L. (1995). Comprehension of narrative and expository texts: The role of content, domain, discourse, and strategy knowledge. In K. Hinchman, D.J. Leu, \& C.K. Kinzer (Eds.), Perspectives on literacy research and practice $44^{\text {th }}$ Yearbook of the National Reading Conference. Chicago, IL: NRC, pp. 197-204

Kintsch, W. (2004). The construction-integration model of text comprehension and its implication for instruction. In R. B. Ruddell \& N. J. Unrau (Eds.), Theoretical models and processes of reading (5th ed.) (pp. 1270-1328). Newark, DE: International Reading Association.

Landis, J.R. \& Koch, G.G. (1977). The measurement of observer agreement for categorical data. Biometrics 33(1): 159-174. doi:10.2307/2529310

Mahwah, Rupley, W. H. (2005). TQG Classroom Observation Form. Unpublished manuscript. College of Education and Human Development, Department of Teaching, Learning, \& Culture, Texas A\&M University.

Martin, K.L., Buelow, S.M., Hoffman, J.T. (2016). New teacher induction: Support that impacts beginning middle-level educators. Middle School Journal, 47(1), 4-12. doi: 10.1080/00940771.2016.1059725

McLaughlin, M. (2012). Reading Comprehension: What every teacher needs to know. The Reading Teacher, 65, 432-40.

Ministry of Education. (2008). A Study of Students' Transition from Primary to Secondary Schooling. Wellington: Research Division.

Muijselaar, M. M. L., Swart, N. M., Steenbeek-Planting, E. G., Verhoeven, L., \& de Jong, P. F. (2017). Developmental relations between reading comprehension and reading strategies, Scientific Studies of Reading, 21(3), 194-209. doi: 10.1080/10888438.2017.1278763 
National Assessment of Educational Progress (2015). U.S. Department of Education, Institute of Education Sciences, National Center for Education Statistics, National Assessment of Educational Progress (NAEP) 2015 Reading Assessment. Retrieved from https://nces.ed.gov/nationsreportcard/

National Middle School Association (2006). Success in the middle: A policymaker's guide to achieving quality middle level education. Westerville, OH: National Middle School Association.

Ness, M. (2007). Reading comprehension strategies in secondary content-area classrooms. Phi Delta Kappan, 89(3), 229-231. doi: 10.1177/003172170708900314

Neufeld, P. (2005). Comprehension instruction in content area classes. The Reading Teacher, 59, 302-312.

O'Brien, D.G., Moje, E.B., \& Stewart, R. (2001). Exploring the content of secondary literacy: Literacy in people's everyday school lives. In E.B. Moje \& D.G. O'Brien (Eds.), Constructions of literacy: Studies of teaching and learning in and out of the secondary classrooms (pp. 105-124). New York, NY: Routledge.

Paige, D. D., Smith, G., Rasinski, V. C., Rupley, W. H., Magpuri-Lavell, T., Nichols, W. D. (2018). The Journal of Educational Research.

Perakyla, A. (2005). Analyzing talk and text. In N. K. Denzin, \& Y. S. Lincoln (Eds.), The sage handbook of qualitative research ( $3^{\text {rd }}$ ed.), pp. 869-886. Thousand Oaks, CA: Sage Publications, Inc.

Pittman, P. \& Honchell, B. (2014). Literature discussion: Encouraging reading interest and comprehension in struggling middle school readers. Journal of Language and Literacy Education, 10(2), 119-133.

Rosenshine, B. (1997). Advances in research on instruction. In J. W. Lloyd, E. J., Kameanui, \& D. Chard (Eds.), Issues in education students with disabilities (pp. 197221).

Rupley, W. H., \& Slough, S. (2010). Building prior knowledge and vocabulary in science in the intermediate grades: Creating hooks for learning. Literacy Research and Instruction, 49, (2), 99-112.

Sam D, P., \& Rajan, P. (2013). Using graphic organizers to improve reading comprehension skills for the middle school ESLl students. English Language Teaching, 6(2), 155-170. doi: 10.5539/elt.v6n2p155

Shanahan, T. \& Shanahan C. (2008). Teaching disciplinary literacy to adolescents: Rething content-area literacy. Harvard Educational Review, 78 (1), pp. 40-59. https://doi.org/10.17763/haer.78.1.v62444321p602101

Shanahan, T. (2012). The common core ate my baby and other urban legends. Educational Leadership, 70(4), 10-16.

Snow, C. E., \& Educational Resources Information Center (2002). Reading for understanding: Toward an RED program in reading comprehension/RAND Reading Study Group; Catherine Snow, chair. RAND, Science \& Technology Policy Institute; U.S. Dept. of Education, Office of Educational Research and Improvement, Educational Resources Information Center.

Stockard, J. (2014). Merging the Accountability and Scientific Research Requirements of the No Child Left Behind Act: Using Cohort Control Groups" Quality and Quantity: International Journal of Methodology, 47(2013), pp. 2225-2257,

Taylor, D. (2007). Fostering engaging and active discussions in middle school classrooms. Middle School Journal, 39(1), 54-59.

Taylor, L. \& Parsons, J. (2011). Improving Student Engagement. Current Issues in Education, 14(1). Retrieved fromhttp://cie.asu.edu/

Texas Education Agency (2016). Snapshot 2016 District Detail. Retrieved from http://rptsvr1.tea.texas.gov/cgi/sas/broker 
U. S. Department of Education, Institute of Education Sciences, National Center for Education Statistics, National Assessment of Educational Progress (NAEP), 2015 Reading Assessment.

Unrau, N.J., \& Quirk, M. (2014). Reading motivation and reading engagement: Clarifying commingled conceptions. Reading Psychology, 35(3), 260-284. doi: 10.1080/02702711.2012.684426

Woolley, G. (2011). Reading comprehension: Assisting children with learning difficulties. Springer Science + Business Media. doi: 10.1007/978-94-007-1174-7_2 